\title{
Pengaruh Pemberian Ekstrak Kedelai (Glycine max) Terhadap Jumlah Pertumbuhan Folikel Ovarium Mencit (Mus musculus)
}

\author{
(THE EFFECT OF SOYBEAN EXTRACT (Glycine max) ON TOTAL GROWTH OF \\ OVARIAN FOLLICLES IN MICE (Mus musculus))
}

\author{
Nugraheni Anggara Pramesti ${ }^{1 *}$, Tjuk Imam Restiadi ${ }^{2}$, Aditya Yudhana ${ }^{3}$, Tatik \\ Hernawati $^{2}$, Iwan Sahrial Hamid ${ }^{4}$, Muhammad Thohawi Elziyad Purnama ${ }^{5}$ \\ ${ }^{1}$ Bachelor of Veterinary Medicine, \\ ${ }^{2}$ Department of Veterinary Reproduction, \\ ${ }^{3}$ Department of Veterinary Parasitology, \\ ${ }^{4}$ Department of Basic Veterinary Science, \\ ${ }^{5}$ Department of Veterinary Anatomy, \\ Faculty of Veterinary Medicine, Universitas Airlangga, \\ UNAIR C-Campus Mulyorejo, Surabaya, Jawa Timur, Indonesia, 60115 \\ Telp. (031)5993016, Fax. (031)5993015 \\ *Corresponding author: nugraheni.anggara.p-2014@fkh.unair.ac.id
}

\begin{abstract}
Abstrak
Penelitian ini bertujuan untuk mengetahui pengaruh ekstrak kedelai (Glycine max) terhadap jumlah pertumbuhan folikel ovarium pada mencit (Mus musculus). Sampel terdiri dari 20 ekor mencit yang secara acak dibagi menjadi lima kelompok. Kelompok kontrol (K) tidak diberi ekstrak kedelai. Kelompok P1 diberi ekstrak kedelai dengan dosis $0,05 \mathrm{mg} / \mathrm{kgBB}$. Kelompok P2 diberi ekstrak kedelai dengan dosis $0,010 \mathrm{mg} / \mathrm{kgBB}$. Kelompok P3 diberi ekstrak kedelai dengan dosis $0,015 \mathrm{mg} / \mathrm{kgBB}$. Kelompok P4 diberikan ekstrak kedelai dengan dosis $0,020 \mathrm{mg} / \mathrm{kgBB}$. Ekstrak kedelai diberikan selama 14 hari. Analisis data menggunakan uji One Way ANOVA dan dilanjutkan dengan uji Honestly Significant Difference (HSD). Hasil penelitian menunjukkan kelompok kontrol $(\mathrm{K})$ memiliki perbedaan signifikan dengan kelompok P1, P2, P3 dan P4. Hasil rata-rata jumlah folikel primer tertinggi terdapat pada perlakuan 4 (P4) dengan dosis $0,020 \mathrm{mg} / \mathrm{kgBB}$ dan jumlah rata-rata folikel sekunder tertinggi pada perlakuan 3 (P3) dengan dosis $0,015 \mathrm{mg} / \mathrm{kgBB}$. Penelitian ini dapat disimpulkan bahwa ekstrak kedelai yang diberikan pada mencit betina dapat meningkatkan jumlah pertumbuhan folikel ovarium dan jumlah rata-rata folikel tertinggi adalah pada perlakuan 3 (P3) dengan dosis $0,015 \mathrm{mg} / \mathrm{kgBB}$.
\end{abstract}

Kata kunci: ekstrak kedelai, folikel, ovarium, mencit

\begin{abstract}
This study aimed to determine the effect of soybean extracts (Glycine max) on the the total number of ovarian follicles growth in mice (Mus musculus). The sample consisted of 20 mice were randomly divided into five groups. The control group $(K)$ was not given the soybean extract. Pl group was given soybean extract with dose $0.05 \mathrm{mg} / \mathrm{kgBW}$. P2 group was given soybean extract with dose of $0.010 \mathrm{mg} / \mathrm{kgBW}$. P3 group was given soybean extract with the dose of $0,015 \mathrm{mg} / \mathrm{kgBW}$. P4 group given soybean extract with dose of $0,020 \mathrm{mg} / \mathrm{kgBW}$. The soybean extracts conducted for 14 days. Data analysis used One Way ANOVA and continued by Honestly Significant Difference (HSD). The results showed the control group $(K)$ has significant difference with P1, P2, $P 3$ and $P 4$ group. The results of the average number of primary follicles were highest for treatment 4 (P4) with dose of $0,020 \mathrm{mg} / \mathrm{kgBW}$ and the average number of secondary follicles were highest in treatment 3 (P3) at a dose of $0.015 \mathrm{mg} / \mathrm{kgBW}$. It can be concluded that soybean extract in female mice can increase the number of ovarian follicles and the highest average number of follicles was on treatment $3(P 3)$ with dose $0.015 \mathrm{mg} / \mathrm{kgBW}$.
\end{abstract}

Key words: soybean extract, follicle, ovary, mice

\section{PENDAHULUAN}

Kedelai merupakan tanaman polongpolongan yang banyak dijumpai di beberapa negara. Masyarakat biasanya mengenal kedelai karena kandungan gizinya. Kedelai memiliki beberapa komponen kandungan gizi diantaranya adalah protein dan minyak nabati (Aldillah, 2014). Kedelai memiliki senyawa yang 
mempunyai aktivitas estrogenik yang disebut dengan fitoestrogen. Senyawa tersebut strukturnya mirip dengan estrogen alami, seperti 17 $\beta$-estradiol (Novarro, 2005). Isoflavon merupakan salah satu golongan dari fitoestrogen. Isoflavon dapat ditemukan pada tanaman leguminosa, seperti kedelai, semua olahan padi, kentang, buah dan sayur (Whitten and Patisaul, 2001).

Hasil penelitian dari Sartini dkk (2014) menunjukkan bahwa kadar isoflavon pada kedelai yang paling tinggi adalah kedelai yang tanpa dihilangkan kulit arinya dan diekstraksi menggunakan cairan penyari metanol dengan kadar isoflavon sebesar $15,9 \%$. Struktur kimia isoflavon yang merupakan senyawa fitoestrogen memiliki kemiripan dengan hormon estrogen, sehingga dapat berikatan dengan reseptor estrogen endogen. Ikatan ini dapat memberikan aktivitas fisiologis sebagai hormon estrogen (Thomsen et al., 2006; Purnama dan Samik, 2014).

Hormon estrogen tersebut disekresikan oleh sel-sel techa iterna folikel ovarium (Feradis, 2010). Hormon estrogen berpengaruh terhadap masa pubertas pada hewan betina. Pubertas hewan betina akan menunjukkan gejala birahi dimana pada saat hewan betina mengalami birahi atau estrus hewan tersebut akan mengovulasikan sel telur. Pertumbuhan folikel ovarium akan dipengaruhi oleh hormon gonadotropin seperti Folicle Stimulating Hormone (FSH) dan Luteinezing Hormon (LH) dan hormon estrogen yang akan memberikan feedback positif pada hipotalamus.

Isoflavon pada kedelai memiliki kandungan yang cukup tinggi sehingga dapat digunakan sebagai bahan penelitian pada bidang reproduksi untuk melihat pengaruh isoflavon terhadap jumlah pertumbuhan folikel ovarium.

\section{METODE PENELITIAN}

\section{Alat dan Bahan}

Penelitian ini menggunakan 20 ekor mencit galur Swiss yang berumur 3,5-4 minggu dengan berat badan antara 20-25 gram dan tidak ada abnormalitas atau sehat. Kebutuhan nutrisi mencit perhari adalah protein $20-25 \%$, lemak 5$12 \%$, serat kasar 2,5 \% dan karbohidrat 45-60\%. Pakan yang diberikan dari PT Charoen Pokphand $^{\circledR}$ dengan jenis pellet. Minum diberikan ad libitum. Kandang dan alas kandang yang digunakan adalah serbuk kayu steril. Tempat pakan dan minum yang digunakan juga dalam keadaan steril.

\section{Perlakuan}

Prosedur penelitian dilakukan dengan uji kode etik hewan coba di Fakultas Kedokteran Hewan Universitas Airlangga kemudian dilakukan persiapan dan penyesuaian hewan coba selama tujuh hari. Pengamatan siklus birahi pada mencit dilakukan dengan swab atau ulas vagina dengan cara flushing dengan cairan $\mathrm{NaCl}$ fisiologis $0,9 \%$ dan diwarnai dengan larutan giemmsa serta diamati di bawah mikroskop. Ekstraksi dilakukan dengan merendam $2 \mathrm{~kg}$ serbuk simplisia biji kedelai dengan 4 liter etanol 96\%. Ekstraksi kedelai berlangsung selama 2 hari kemudian disaring agar mendapatkan filtratnya. Filtrat dipekatkan menggunakan rotary evaporator pada suhu $\pm 70^{\circ} \mathrm{C}$.

Dosis ekstrak kedelai pada penelitian ini adalah (P1) $\quad 0,005 \quad \mathrm{mg} / \mathrm{kgBB}, \quad$ (P2) $\quad 0,010$ $\mathrm{mg} / \mathrm{kgBB}$, (P3) 0,015 mg/KgBB, (P4) 0,020 $\mathrm{mg} / \mathrm{kgBB}$. Pemberian ekstrak kedelai pada mencit dilakukan secara peroral dengan menggunakan sonde lambung. Ekstrak kedelai dilarutkan dengan larutan CMC-Na untuk memudahkan ekstrak masuk ke dalam lambung mencit. Perlakuan dilakukan selama 14 hari

Mencit betina dikorbankan pada hari ke 15 dengan cara dislokasi leher kemudian dilakukan pembedahan untuk mengambil jaringan ovarium. Pengamatan jumlah folikel dilakukan dengan pengambilan ovarium kemudian dibuat sediaan histologi.

\section{Pengamatan}

Jumlah pertumbuhan folikel ovarium diamati di bawah mikroskop trinokuler Nikon ${ }^{\circledR}$ Eclipse E200 dengan perbesaran 100 kali. Pengamatan dilakukan dengan melihat jumlah folikel primer, sekunder, tersier, dan folikel de Graaf ovarium. Pengamatan dilakukan dengan memeriksa 
seluruh lapangan pandang pada masing-masing preparat. Perhitungan jumlah folikel dilakukan pada kedua ovarium kanan dan kiri kemudian dirata-ratakan. Hasil perhitungan dari pengamatan kemudian dianalisis statistik.

\section{Analisis Data}

Data yang telah diperoleh dianalisis statistik Uji One Way Anova (Analysis of Variance) untuk mengetahui perbedaan pengaruh dari beberapa perlakuan. Jika terdapat perbedaan maka dilakukan uji Honestly Significant Difference (HSD).

\section{HASIL DAN PEMBAHASAN}

Hasil uji One Way ANOVA untuk jumlah folikel ovarium mencit menunjukkan adanya perbedaan yang nyata $(\mathrm{p}<0,05)$. Uji Honestly Significant Difference (HSD) digunakan untuk mengetahui perbedaan dari setiap kelompok perlakuan.

Tabel 1. Rata-rata jumlah folikel pada tiap kelompok perlakuan

\begin{tabular}{cccc}
\hline Perlakuan & $\begin{array}{c}\text { Jumlah Rata-rata } \\
\text { Folikel Ovarium Kiri }\end{array}$ & $\begin{array}{c}\text { Jumlah Rata-rata } \\
\text { Folikel Ovarium Kanan }\end{array}$ & Mean \pm SD \\
\hline K & 5,25 & 5,75 & $5,50^{\mathrm{a}} \pm 0,408$ \\
P1 & 12,25 & 12,25 & $12,25^{\mathrm{b}} \pm 0,866$ \\
P2 & 16,25 & 16,25 & $16,50^{\mathrm{c}} \pm 0,288$ \\
P3 & 20,25 & 19,25 & $19,75^{\mathrm{d}} \pm 0,288$ \\
P4 & 24,5 & 24 & $23,50^{\circ} \pm 1,190$
\end{tabular}

Keterangan: superskrip berbeda pada kolom yang sama menunjukkan hasil berbeda nyata $(\mathrm{p}<0,05)$

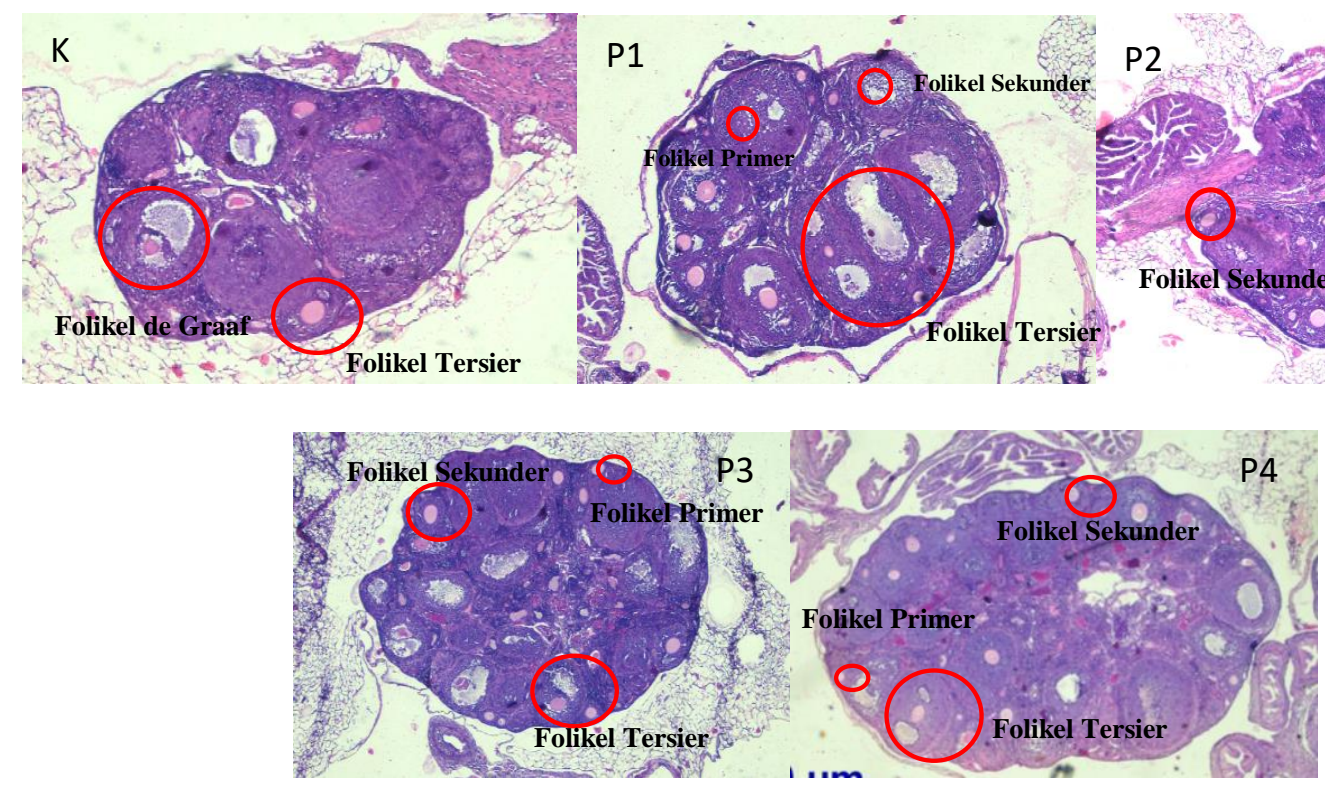

Gambar 1. Gambaran histopatologi ovarium pada masing-masing perlakuan dengan pertumbuhan folikel pada bagian korteks

Hasil uji Honestly Significant Difference (HSD) menunjukkan kelompok kontrol (K) memiliki perbedaan jumlah folikel ovarium yang signifikan terhadap kelompok P1, P2, P3 dan P4 $(\mathrm{p}<0,05)$. Kelompok perlakuan $1(\mathrm{P} 1)$ memiliki perbedaan yang signifikan terhadap kelompok K,
P2, P3 dan P4 ( $\mathrm{p}<0,05)$. Kelompok perlakuan 2 (P2) memiliki perbedan yang signifikan terhadap kelompok K, P1, P3 dan P4 (p<0,05). Kelompok perlakuan 3 (P3) memiliki perbedaan yang signifikan terhadap kelompok K, P1, P2 dan P4 $(\mathrm{p}<0,05)$. 
Grafik perbandingan jumlah rata-rata folikel primer, sekunder, tersier dan de Graaf antara kelompok kontrol dan kelompok perlakuan menunjukkan terdapat perbedaan pada jumlah folikel primer dan sekunder. Kelompok kontrol (K) memiliki jumlah rata-rata folikel primer dan sekunder yang lebih rendah dari kelompok perlakuan P1, P2, P3 dan P4 dengan jumlah ratarata folikel primer 2,5 dan rata-rata jumlah folikel sekunder 2,5. Kelompok P1 memiliki jumlah rata-rata folikel primer 4,5 dan jumlah rata-rata folikel sekunder 5,25. Kelompok P2 memiliki jumlah rata-rata folikel primer 6,25 dan jumlah rata-rata folikel sekunder 10. Kelompok P3 memiliki jumlah rata-rata folikel primer mengalami penurunan yakni 5,75 dan jumlah rata-rata folikel sekunder mengalami peningkatan yakni 12,25 . Kelompok P4 memiliki jumlah rata-rata folikel primer 11 dan jumlah rata-rata folikel sekunder 10,75. Hasil rata-rata jumlah folikel tersier dan folikel de Graaf pada kelompok kontrol dan kelompok perlakuan tidak berbeda nyata. Rata-rata jumlah folikel primer yang tertinggi adalah hasil dari perlakuan $4(\mathrm{P} 4)$ dengan dosis $0,020 \mathrm{mg} / \mathrm{kgBB}$. Rata-rata jumlah folikel sekunder yang tertinggi ditunjukkan pada grafik perlakuan $3(\mathrm{P} 3)$ dengan dosis $\mathrm{P} 30,015$ $\mathrm{mg} / \mathrm{kgBB}$ dengan jumlah rata-rata folikel 12,25.

Kedelai merupakan salah satu tanaman yang mengandung isoflavon. Isoflavon dalam tanaman kedelai dapat berikatan dengan reseptor estrogen yang ada di dalam tubuh (El-Shelmy, 2011). Struktur kimia isoflavon pada kedelai memiliki kemiripan dengan hormon estrogen yaitu $17 \beta$ estradiol. Reseptor estrogen dalam tubuh dapat berikatan dengan senywa isoflavon sehingga dapat memberikan aktivitas fisiologis sebagai hormon estrogen (Thomsen et al., 2006; Purnama et al., 2017). Pemberian estrogen dosis tinggi pada tikus (50-100 $\mu \mathrm{g})$ menghambat ovulasi (menghambat pengeluaran Folicle Stimulating Hormone dan Luteinizing Hormone) dan pemberian dosis rendah (kurang dari $50 \mu \mathrm{g}$ ) meningkatkan sekresi FSH dan LH (Sarwono, 1994 dalam Limbong, 2003). Hasil penelitian Prabowo (2014) pemberian ekstrak kedelai dengan dosis 7,5 mg/ 200 gramBB tikus dapat meningkatkan jumlah folikel ovarium.
Pemberian dosis diatas 7,5 mg/ 200 gramBB tikus menyebabkan penurunan jumlah folikel ovarium tikus. Hal tersebut terjadi akibat sekresi hormon gonadotropin dan GnRH dihambat oleh pemberian senyawa fitoestrogen.

Perkembangan folikel ovarium dipengaruhi oleh hormon estrogen, hormon estrogen dihasilkan oleh sel techa interna dari folikel ovarium. Perkembangan serta pematangan folikel dan sekresi estrogen dikendlikan oleh hormon gonadotropin. Hormon gonadotropin dari hipofisis diantaranya adalah hormon Follicle Stimulating Hormone (FSH) dan Luteinizing Hormone (LH). Estrogen yang disekresikan oleh ovarium akan memicu pelepasan hormon LH untuk mengovulasikan oosit pada fase estrus. LH berfungsi untuk merangsang korpus luteum sedangkan estrogen mempengaruhi sekresi hormon gonadotropin melalui umpan balik positif pada hipotalamus (McGee and Aaron, 2000).

Reseptor estrogen spesifik, sehingga hanya dapat mengikat molekul yang memiliki struktur yang mirip dengan hormon estrogen. Fitoestrogen merupakan senyawa yang mirip dengan hormon estrogen sehingga dapat berikatan dengan reseptor estrogen pada tubuh. Molekul estrogen akan mengikat resptor membentuk ikatan ligand-hormone receptor. Pengikatan tersebut dimungkinkan karena molekul estrogen memiliki bentuk atau struktur yang mirip untuk berikatan. Ikatan tersebut akan merangsang proses seluler tubuh yang spesifik sehingga terjadi pengaktifan gen spesifik untuk memicu pembentukan protein agar proses metabolisme sel berlangsung (Eddy, 2006 dalam Rejeki, 2017). Reseptor estrogen (ER) dalam ovarium terdapat pada inti sel granulosa, sel epitel germinal, sel interstitial dan sel techa dari folikel primer, sekunder dan folikel yang matang (Cheng et al, 2002).

Perkembangan folikel sekunder terjadi akibat pengaruh pemberian ekstrak kedelai yang memiliki kandungan fitoestrogen. Perbedaan yang tidak nyata pada jumlah rata-rata folikel tersier dan folikel de Graaf terjadi pada semua kelompok, baik kelompok kontrol maupun kelompok perlakuan. Perkembangan folikel 
tersier dan folikel de Graaf tidak memiliki perbedaan yang nyata dapat diakibatkan oleh adanya atresia (kerusakan) folikel dan pengaruh dari respon masing-masing hewan coba itu sendiri. Penelitian ini menunjukkan adanya peningkatan jumlah pertumbuhan folikel selaras dengan penelitian Prabowo (2014) pemberian ekstrak kedelai dengan dosis 7,5 mg/ 200 gramBB tikus dapat meningkatkan jumlah folikel ovarium.

\section{KESIMPULAN}

Pemberian ekstrak kedelai (Glycine max) pada mencit betina (Mus musculus) dapat meningkatkan jumlah folikel ovarium. Rata-rata jumlah folikel yang tertinggi adalah pada perlakuan 3 (P3) dengan dosis $0,015 \mathrm{mg} / \mathrm{kgBB}$.

\section{UCAPAN TERIMA KASIH}

Peneliti mengucapkan terima kasih kepada PSDKU Banyuwangi Universitas Airlangga atas izin yang diberikan dan fasilitas untuk melaksanakan penelitian.

\section{DAFTAR PUSTAKA}

Aldillah, R. 2014. Analisis Produksi Dan Konsumsi Kedelai Nasional. [Tesis] Fakultas Kedokteran Institut Pertanian Bogor. Hal.9-30.

Blackburn, S.T. 2013. Maternal, Fetal, \& Neonatal Physiology, A Clinical Perspective, 4th Edition. Philadelphia (USA): Elsevier Inc. p29-53.

Bolla, K.N. 2015. Soybean Consumption And Health Benefits. Int J Sci Tech Res, 4: 50-3.

Bustamam, N. 2008. Fitoestrogen dan kesehatan tulang. Bina Widya, 19(3): 146-150.

Byers, S.L., M.V. Wiles, S.L. Dunn, and R.A. Taft. 2012. Mouse estrous cycle identification tool and images. PloS one, 7(4): 1-4.
Cheng, G., Z. Weihua, S. Makinen, S. Makela, S. Saji, M. Warner, G. Jan-Ake, dan O. Hovatta. 2002. A role for the androgen receptor in follicular atresia of estrogen receptor beta knockout mouse ovary. Biol Repro, 66(1): 77-84.

El-Shemy, H.A. 2011. Soybean and nutrition. Tech. Publish, Rijeka, Croatia, 2: $72-85$.

Feradis. 2010. Reproduksi Ternak. Bandung: Alfabeta. Hal.33-74.

Ganong, W.F. 2003. Fisiologi Kedokteran. Ed ke-20. Widjajakusumah HM, penerjemah: Djauhari, editor. Jakarta: EGC. Terjemahan dari medical physiology. Hal.165-176.

Gueven, A., and D. Knorr. 2011. Isoflavonoid production by soy plant callus suspension culture. J Food Engine, 103(3): 237-243.

Gupta, C., D. Prakash, and S. Gupta. 2016. Phytoestrogens as pharma foods. Adv Food Technol Nutr Sci Open J, 2(1): 19-31.

Hafez, E.S.E., M.R. Jainudeen, and Y. Rosnina. 2000. Hormones, growth factors, and reproduction. Reproduction in farm animals. Lippincott, Williams and Wilkins, Baltimore, MA, USA. p33-54.

Haliza, W., Endang, Y. dan Thahir, R. 2007. Pemanfaatan Kacang-kacangan Lokal sebagai Subtitusi Bahan Baku Tempe dan Tahu. Buletin Teknologi Pascapanen Pertanian, 3: 1-8.

Indriani, Ghina. 2014. Peran Pemberian Ekstrak Tempe terhadap Kinerja Reproduksi Tikus Betina Usia Lepas Sapih. [Skripsi]. Fakultas Kedokteran Hewan Institut Pertanian Bogor. Hal.2-5.

Ismudiono, P. S., H. Anwar, S.P. Madyawati, A. Samik, \& E. Safitri. 2010. Fisiologi 
Reproduksi pada Ternak. Bagian Reproduksi Fakultas Kedokteran Hewan Universitas Airlangga, Surabaya. Hal.55-56.

Laurence, D.R., and Bacharach, A.L. 1964. Evaluation of drug activities: pharmacometrics. New York: Academic press. 1: 183-205.

Leung, P.C., and E.Y. Adashi. 2003. The ovary. Elsevier. (Second edition.). p111-439.

Lewis, V. 2007. Reproductive Endocrinology and Infertility. Landes Bioscience. p4-9.

Limbong, T. 2003. Pengaruh Ekstrak Etanol Kulit batang Pakettu (Ficus superba Miq) Terhadap Folikulogenesis Ovarium Mencit (Mus musculus): Penelitian Eksperimental Laboratoris [Disertasi] Fakultas Kedokteran Hewan Universitas Airlangga. Hal.6-60.

Lohmiller, J.J., and S.P. Swing. 2006. Reproduction and breeding. The Laboratory Rat. 2nd Ed. Elsevier Academic Press, London, UK. p153.

Mateos-Apricio, I., C.A. Redondo, M.J. Villanueva-Suarez, and M.A. ZapataRevilla. 2008. Soybean, a promising health source. Nutricion hospitalaria, 23(4): 305312.

Marquez, R.S., H. Hernandez, J.A. Flores, G. Munoz, M. Gerardo, G. Duarte, J. Vielma, and J.A. Delgadillo. 2012. Effects of phytoestrogens on mammalian reproductive physiology. Trop Subtrop Agroecosys, 15(1): 129-145.

McGee, E. A., and J.W.H. Aaron. 2000. Initial and Cyclic Recruitment of Ovarian Follicles. Endocrine rev, 21(2): 200-214.

Mitchell, J. H., E. Cawood, D. Kinniburgh, A. Provan, A.R. Collins, and D.S. Irvine. 2001. Effect of a phytoestrogen food supplement on reproductive health in normal males. Clin Sci, 100(6): 613-618.

Muhiddin, S.T. 2013. Peran Ekstrak Tempe pada Masa Prapubertas terhadap Kinerja Reproduksi Tikus Betina Rattus norvegicus. [Skripsi] Fakultas Kedokteran Hewan Institut Pertanian Bogor. Hal.2-9.

Mujic, I., E. Sertovic, S. Jokic, Z. Saric, V. Alibabic, S. Vidovic, and J. Zivkovic. 2011. Isoflavone content and antioxidant properties of soybean seeds. Croatian J Food Sci Tech, 3(1): 16-20.

Mulyati, B. 2016. Studi Komputasi Interaksi Isoflavon dengan Reseptor Estrogen $\beta$ Menggunakan Metode Oniom. EduChemia. Jurnal Kimia dan Pendidikan, 1(2): 137148.

Murkies, A.L., G. Wilcox, and S.R. Davis. 1998. Phytoestrogens. $J$ Clin Endocrinol Metab, 83(2): 297-303.

Novarro, M.C. 2005. Mecanismo de ación de las isoflavonas. Ginelogía y Obstetricia Clínica, 6: $159-165$.

Naya, M., and I. Masanao, I. 2013. Recent Advances on Soybean Isoflavone Extraction and Enzymatic Modification of Soybean Oil. Soybean-Bio-Active Compounds. In Tech Chapter, 19: 430-452.

Pavlik, R., G. Wypior, S. Hect, P. Papadopoulos, M. Kupka, C. Thaler, I. Wiest, A. Pestka, K. Friese, and U. Jeschke. 2011. Induction of G protein-coupled estrogen receptor (GPER) and nuclear steroid hormone receptors by gonadotropins in human granulosa cells. Histochem Cell Biol, 136(3): 289.

Pelletier, G., and M. El-Alfy. 2000. Immunocytochemical localization of estrogen receptors $\alpha$ and $\beta$ in the human reproductive organs. $J$ Clin Endocrinol Metab, 85(12): 4835-4840. 
Prabowo, H.A. 2014. Pengaruh Pemberian Ekstrak Kedelai (Glycine max, L.) terhadap Jumlah Folikel Ovarium pada Tikus Putih (Rattus norvegicus, L.). Diss. Universitas Yogyakarta. Hal.1-6.

Primiani, C.N. 2013. Potensi Tepung Tempe sebagai Estrogen Alami terhadap Uterus Mencit Premenopause. Sains Matematika,1(2): 47-51.

Purnama, M.T.E., \& A. Samik. 2014. Potensi Mycotoxin Binders Terhadap Gambaran Histopatologi Neoplasia Kelenjar Mammae Mencit (Mus musculus) Bunting yang Terpapar Zearalenon. Veterinaria, 7(1).

Purnama, M.T.E., I. Mustofa, T.W. Suprayogi, A. Samik, R.A. Prastiya, \& A.L. Saputro. 2017. Aluminosilikat Berpotensi Menekan Gangguan Reproduksi Mikotoksin Zearalenon Berdasarkan Pengamatan Jumlah Folikel dan Ekspresi Caspase-9 Ovarium. Jurnal Veteriner, 18(2): 175-180.

Rejeki, R.T., H. Tri, dan Sukiya. 2017. Pengaruh Ekstrak Daun Kenari (Canarium indicum, L.) terhadap Perkembangan Folikel Ovarium Tikus Putih Betina (Rattus norvegicus, L.). Biologi-S1, 6(3): 194-203.

Ruggiero, R.J., and F.E. Likis. 2002. Estrogen: physiology, pharmacology, and formulations for replacement therapy. J Midwifery Women's Health, 47(3): 130-138.

Saeed, N.A.H.A.A., I.M. Al-Kadmy, L.J. Ibraheem, H.F.D. Al-Lami, \& S.N. Aziz. 2017. The effect of Soybean (Glycine max) Aqueous Extract on Ovarian Structure in White Female Rats. Mintage J Pharm Med Sci, 21-22.

Safrida. 2008. Perubahan Kadar Hormon Estrogen pada Tikus yang Diberi Tepung Kedelai dan Tepung Tempe. [Tesis] Bogor Institut Pertanian Bogor. Hal.32-56.
Sartini. M.N. Djide, dan A.D. Permana. 2014. Ekstraksi Isoflavon Kedelai dan Penentuan Kadarnya Secara Ultra Fast Liquid Chromatography (UFLC). Sainsmat, 3(2): 130-134.

Sarwono. 1994. Ilmu Kandungan. Yayasan Bina Pustaka Sarwono Prawihardjo. Jakarta. Hal.544-643.

Scudamore, C.L. 2014. A Practical Guide to the Histology of the Mouse. John Wiley \& Sons. p109-120.

Sherwood, L. 2001. Fisiologi Manusia dari Sel ke Sistem. Brahm, penerjemah; Santoso BI, editor. Jakarta: EGC. Terjemahan dari: Human Physiology: from cells to systems. p196-210.

Sitasiwi, A.J. 2008. Hubungan Kadar Hormon Estradiol 17- $\hat{I}^{2}$ dan Tebal Endometrium Uterus Mencit (Mus musculus 1.) selama Satu Siklus Estrus. Anatomi Fisiologi, 16(2): $38-45$.

Stormshak, F. 2005. Comparative endocrinology. Endocrinology. Humana Press. p149-150.

Suarsana, I.N., D.I.N. Sadra, I.W. Gorda, dan P.B. Pontjo. 2011. Tepung Tempe Kaya Isoflavon Meningkatkan Kadar Kalsium, Posfor dan Estrogen Plasma Tikus Betina Normal. Jurnal Veteriner, 12(3): 229-234.

Tempfer, C.B., E.K. Bentz, S. Leodolter, G. Tscherne, F. Reuss, H.S. Cross, \& J.C. Huber. 2007. Phytoestrogens in clinical practice: a review of the literature. Fertility and sterility, 87(6): 1243-1249.

Thomsen, A.R., K. Almstrup, J.E. Nielsen, I.K. Sørensen, O.W. Petersen, H. Leffers, \& V.M. Breinholt. 2006. Estrogenic effect of soy isoflavones on mammary gland 
morphogenesis and gene expression profile. Toxicol Sci, 93(2): 357-368.

Treuting, P.M., S.M. Dintzis, and K.S. Montine. (Eds.). 2017. Comparative Anatomy and Histology: A Mouse, Rat, and Human Atlas. Academic Press. Hal.303-330.

Urasopon, N., Y. Hamada, K. Asaoka, U. Poungmali, \& S. Malaivijitnond. 2008. Isoflavone content of rodent diets and its estrogenic effect on vaginal cornification in
Pueraria mirifica-treated rats. Sci Asia, 34(4): 371-376.

Whitten, P.L., and H.B. Patisaul. 2001. Crossspecies and interassay comparisons of phytoestrogen action. Environment Health Perspectives, 109 Suppl 1(5): 71-73.

Winarsi, H. 2010. Protein Kedelai dan Kecambah Manfaatnya bagi Kesehatan. Yogyakarta: Kanisius. Hal.16-25. 